\title{
Convective Initiation by Topographically Induced Convergence Forcing over the Dabie Mountains on 24 June 2010
}

\author{
Qiwei WANG ${ }^{1}$, Ming XUE ${ }^{* 1,2}$, and Zhemin TAN ${ }^{1}$ \\ ${ }^{1}$ Key Laboratory of Mesoscale Severe Weather and School of Atmospheric Sciences, \\ Nanjing University, Nanjing 210023, China \\ ${ }^{2}$ Center for Analysis and Prediction of Storms and School of Meteorology, \\ University of Oklahoma, Norman, Oklahoma 72072, USA
}

(Received 11 March 2016; revised 13 June 2016; accepted 13 June 2016)

\begin{abstract}
The initiation of convective cells in the late morning of 24 June 2010 along the eastward extending ridge of the Dabie Mountains in the Anhui region, China, is studied through numerical simulations that include local data assimilation. A primary convergence line is found over the ridge of the Dabie Mountains, and along the ridge line several locally enhanced convergence centers preferentially initiate convection. Three processes responsible for creating the overall convergence pattern are identified. First, thermally-driven upslope winds induce convergence zones over the main mountain peaks along the ridge, which are shifted slightly downwind in location by the moderate low-level easterly flow found on the north side of a Mei-yu front. Second, flows around the main mountain peaks along the ridge create further convergence on the lee side of the peaks. Third, upslope winds develop along the roughly north-south oriented valleys on both sides of the ridge due to thermal and dynamic channeling effects, and create additional convergence between the peaks along the ridge. The superposition of the above convergence features creates the primary convergence line along the ridge line of the Dabie Mountains. Locally enhanced convergence centers on the primary line cause the initiation of the first convection cells along the ridge. These conclusions are supported by two sensitivity experiments in which the environmental wind (dynamic forcing) or radiative and land surface thermal forcing are removed, respectively. Overall, the thermal forcing effects are stronger than dynamic forcing given the relatively weak environmental flow.
\end{abstract}

Key words: Dabie Mountains, convective initiation, low-level convergence line, thermal forcing, dynamic forcing

Citation: Wang, Q. W., M. Xue, and Z. M. Tan, 2016: Convective initiation by topographically induced convergence forcing over the Dabie Mountains on 24 June 2010. Adv. Atmos. Sci., 33(10), 1120-1136, doi: 10.1007/s00376-016-6024-z.

\section{Introduction}

Complex terrain plays important roles in the initiation and organization of convection (e.g., Rotunno and Houze, 2007; Wulfmeyer et al., 2008; Houze, 2012; Kain et al., 2013; Trier et al., 2015; Worthington, 2015; Zhao, 2015). For strong airflows encountering complex terrain, dynamic forcing can be strong enough to cause convective initiation (CI). For weak environmental airflows, the dynamic effects tend to be weaker, meaning CI is often caused mainly by thermally-driven mountain wind systems. For moderate environmental airflows, both dynamic and thermal effects associated with the complex terrain can be important. The dynamic and thermal effects of mountains on CI and precipitation have been investigated in a number of studies for mountains in the United States and Europe, as well as for idealized mountains (e.g., Crook and Tucker, 2005; Tucker and Crook, 2005;

\footnotetext{
* Corresponding author: Ming XUE

Email:mxue@ou.edu
}

Demko and Geerts, 2010; Schmidli and Rotunno, 2010; Bennett et al., 2011; Hagen et al., 2011; Soderholm et al., 2014). Low-level convergence forcing induced by dynamically and/or thermally-driven local wind systems have been found to be of importance for CI over mountainous terrain. Most current operational models are, however, still unable to successfully represent the detailed flow interactions and associated CI over complex terrain, due to inadequate model resolution, model physics errors, and a lack of observations providing accurate enough initial conditions (e.g., Horel et al., 2002; Bosart, 2003; Zhong and Fast, 2003; Chow et al., 2013).

Climatological studies over the middle and lower reaches of the Yangtze River in eastern China (e.g., Bao et al., 2011; Luo et al., 2013) suggest that convection and associated precipitation are to some extent linked to terrain in the region. The Dabie Mountains is the primary mesoscale mountain range located in the region, which has a horizontal width of about $200 \mathrm{~km}$ and a height of about $1 \mathrm{~km}$ (Wang and Tan, 2006). A number of studies (e.g., Tao, 1980; Sun et al., 2005; 


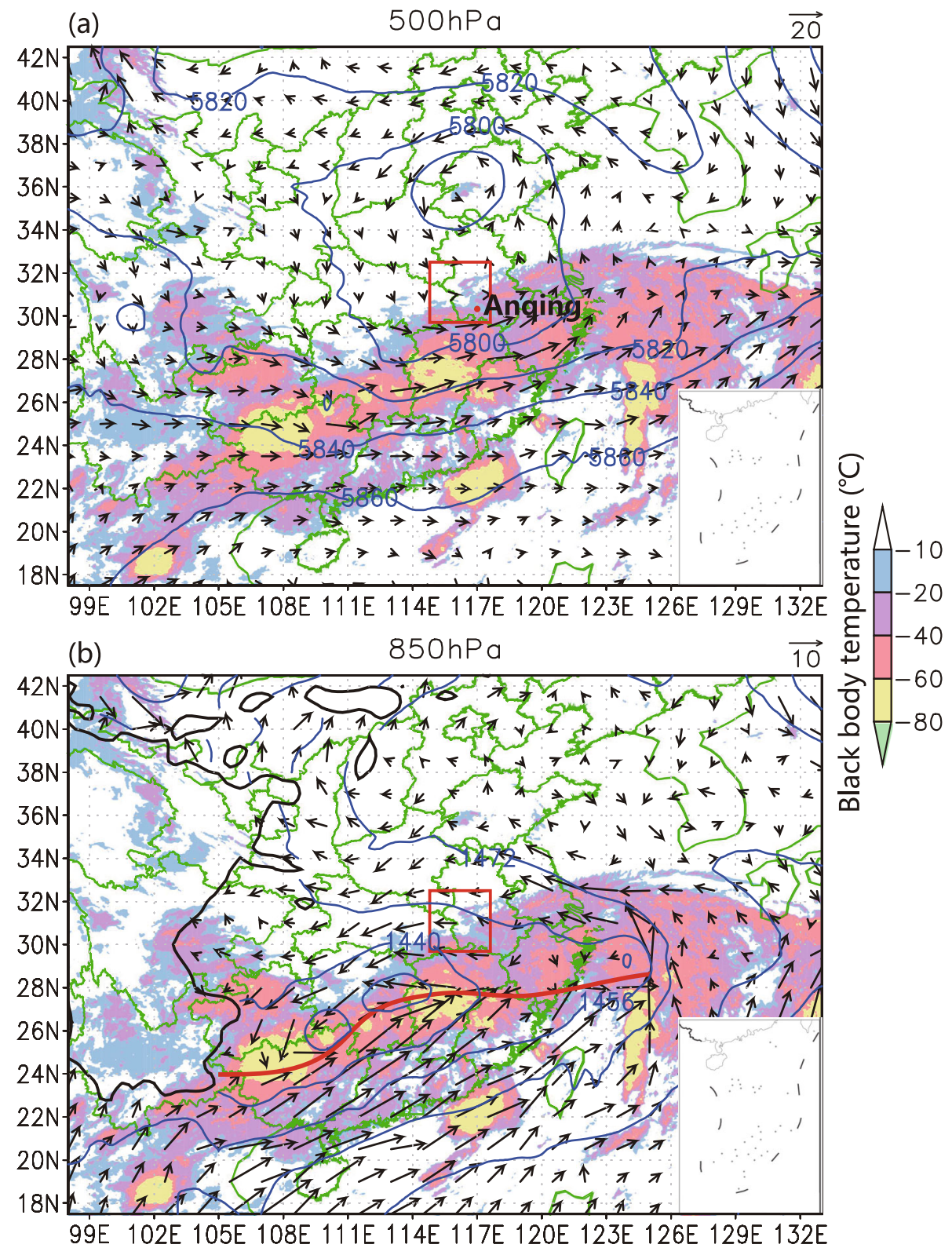

Fig. 1. Geopotential height (blue contours, units: gpm) and wind fields (vectors, units: $\mathrm{m} \mathrm{s}^{-1}$ ) from the NCEP operational GFS $0.5^{\circ}$ global analysis at 0000 UTC 24 June 2010 at (a) 500 $\mathrm{hPa}$ and (b) $850 \mathrm{hPa}$. The black body temperature (color-shaded; units: ${ }^{\circ} \mathrm{C}$ ) is superimposed to show regions of clouds or convection associated with the Mei-yu front that features a shear line at $850 \mathrm{hPa}$ (bold red curved line). The red box outlines the Dabie Mountains region shown in Fig. 2, and is also shown in Fig. 4. The location of the Anqing sounding is marked by a red dot in (a). The country/province borders are drawn in bold green. The bold black lines in (b) indicate where the $850 \mathrm{hPa}$ pressure level intersects the terrain.

Yang et al., 2010; Fu et al., 2012; Sun and Zhang, 2012; Zhao et al., 2012; Guo et al., 2013; Miao et al., 2014) have investigated the general influences of the Dabie Mountains on convection and precipitation along the Mei-yu front ${ }^{\mathrm{a}}$, which is a prominent precipitating system that produces persistent rainfall along the Yangtze River in early summer. In spite of these studies, the role of the Dabie Mountains in initiating convection during the Mei-yu season has received little attention. During the Mei-yu season, especially in the Meiyu frontal zone, the environmental airflows are usually relative weak, and the relative roles of dynamic versus thermodynamic forcing of the Dabie Mountains in producing and supporting convection are not well understood. Documenting and understanding the CI processes associated with the Dabie Mountains is important for improving the prediction of convection and precipitation in this region, especially given that

\footnotetext{
"A Mei-yu front is a quasi-stationary or slow-moving frontal system over East Asia, and is also called "Baiyu" in Japan and "Changma" in Korea (e.g., Ding, 1992; Chen et al., 1998; Zhang and Tan, 2009).
} 
convection can develop and propagate eastward into the even more heavily populated coastal regions and impose considerable socioeconomic impacts. This paper studies one such event.

During 24 June 2010, a moderate low-level easterly airflow north of a Mei-yu front occupied the Dabie Mountains region. At 0000 UTC 24 June 2010 (Fig. 1), a cloud band associated with the Mei-yu front was situated on the south side of the Dabie Mountains region (red box in Fig. 1). Climatologically, this type of synoptic situation tends to persist for around one week during the Mei-yu season, which gener- ally lasts approximately 20 to 25 days from late June to early July. The precipitation band associated with a Mei-yu front is generally situated south of $31^{\circ} \mathrm{N}$ (Ding et al., 2007), which is the latitude of the center of the Dabie Mountains. In the present case, westerly flow at the $500 \mathrm{hPa}$ level associated with a cut-off low dominated over the Dabie Mountains region (Fig. 1a), while an easterly flow of approximately $5 \mathrm{~m}$ $\mathrm{s}^{-1}$ was situated on the north side of the Mei-yu front (indicated by the shear line) at the $850 \mathrm{hPa}$ level (Fig. 1b). The easterly flow still extended to the surface and was slightly weaker (Fig. 2a). The near-surface specific humidity was
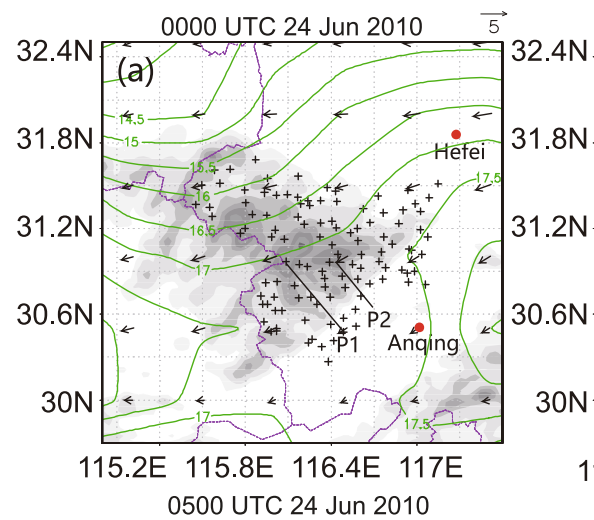

0400 UTC 24 Jun 2010
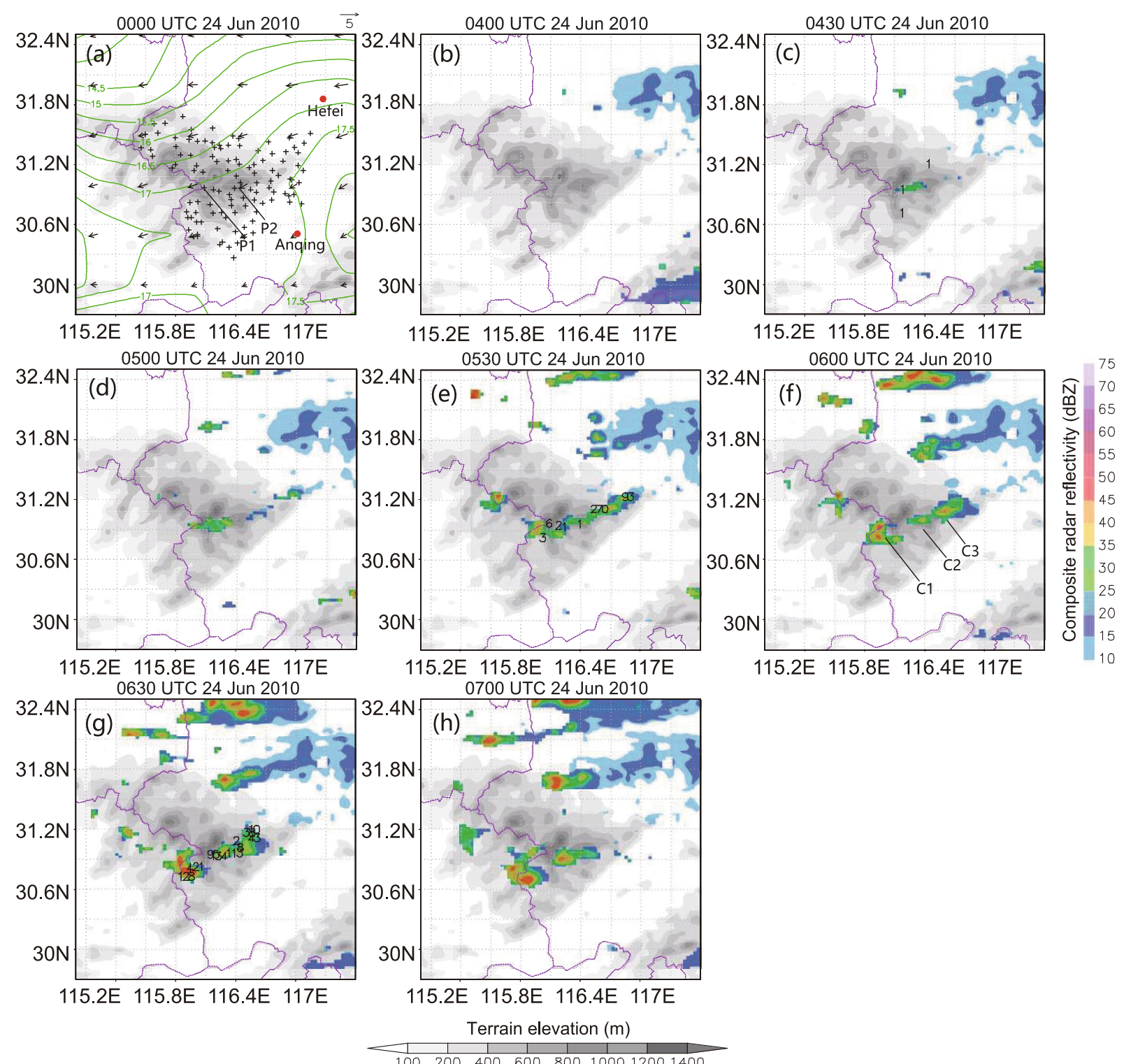

Fig. 2. Observed composite radar reflectivity (color-shaded; units: dBZ) from Hefei Doppler weather radar at (a) 0000 UTC, (b) 0400 UTC, (c) 0430 UTC, (d) 0500 UTC, (e) 0530 UTC, (f) 0600 UTC, (g) 0630 UTC, and (h) 0700 UTC 24 June 2010. Also shown in (a) are the $10 \mathrm{~m}$ wind vectors and $2 \mathrm{~m}$ specific humidity (green contours) from NCEP GFS analysis, and locations of the automatic weather stations (plus signs) for rain gauge measurements. The Hefei radar and Anqing sounding locations are also shown as red filled circles with labels in (a). Hourly precipitation (in $0.1 \mathrm{~mm}$ ) at 0500 UTC, 0600 UTC and 0700 UTC from the automatic weather stations are shown in (c), (e) and (g), respectively. The terrain elevation is shaded in gray and the plotted region corresponds to the red box shown in Fig. 1. The important mountain peaks are labelled P1 and P2 in (a). The three cells initiated in the hour before 0600 UTC along a convergence line are labelled as C1, C2 and C3 in (f). 
around $17 \mathrm{~g} \mathrm{~kg}^{-1}$ (Fig. 2a) — a very moist environmental condition favorable for convection.

Observations show that convective cells initiated along a line over the Dabie Mountains. The first weak reflectivity echoes occurred on the eastern edge of the Dabie Mountains (Fig. 2b) and between mountain peak P1 and P2 (Fig. 2c). A line of weak echoes or convective cells along the eastward extending ridge of the Dabie Mountains could be identified by 0500 UTC (Fig. 2d) and 0530 UTC (Fig. 2e), respectively. The convective cells along the line produced a line of precipitation echoes within an hour (Fig. 2e), which later evolved into three larger convective cell groups, labelled $\mathrm{C} 1, \mathrm{C} 2$ and $\mathrm{C} 3$ in Fig. 2f. The three cell groups changed only slightly in location and produced considerable precipitation of more than $10 \mathrm{~mm}$ in the following hour (Figs. $2 \mathrm{~g}$ and $\mathrm{h}$ ). More than $30 \mathrm{~mm}$ of rainfall within $3 \mathrm{~h}$ between 0500 and 0800 UTC was observed at some of the automatic weather stations (figure not shown), which indicates that the CIs led to a significant weather event with short-duration heavy precipitation.

The environment for CI over the Dabie Mountains is indicated by a sounding (Fig. 3) averaged from the GFS analysis data at 0000 UTC over the box region shown in Fig. 1. Both the GFS average sounding and the observed sounding at An- qing (see Fig. 2a for its location) near the Dabie Mountains feature relatively weak low-level easterly flows. The temperature difference between the two soundings is small, except near the surface due to local modifications of the flow by surrounding mountains at Anqing. The GFS average and Anqing sounding moisture profiles show large differences, with the latter showing much higher relative humidity in a deep layer. This is believed to be because Anqing was at that time in a moister and more unstable environment close to the Mei-yu front and associated clouds. The average GFS sounding is believed to better represent the thermodynamic and wind structures of the background flow over the Dabie Mountains region. The background flow provides an environment of moderate CAPE (approximately $924 \mathrm{~J} \mathrm{~kg}^{-1}$ ) and weak convective inhibition (approximately $-26 \mathrm{~J} \mathrm{~kg}^{-1}$ ).

The line of convection was unlikely to be a direct result of mountain-flow interactions, since such interactions typically trigger upslope or leeside convection instead of convection on both sides of mountain peaks at the same time, as seen here. Besides, the environmental flows appear to have been too weak to have directly forced convection. Nor does it appear to have been purely a result of thermally-driven circulations, which typically trigger convection over mountain

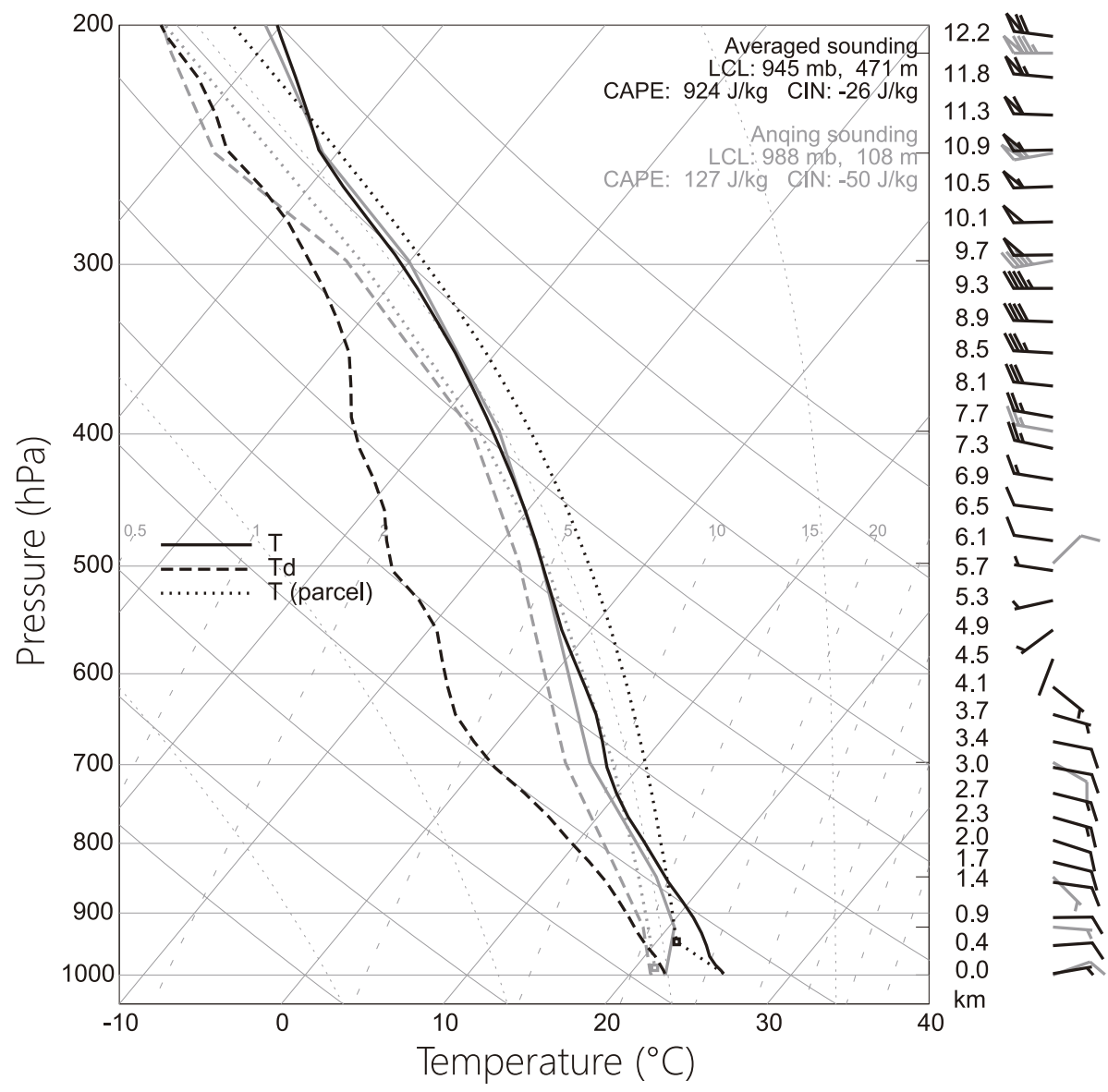

Fig. 3. The sounding averaged from the GFS analysis data at 0000 UTC 24 June 2010 over the Dabie Mountains region within the box in Fig. 1 (black lines and wind barbs). The observed Anqing sounding near the Dabie Mountains at the same time is shown for comparison (gray lines and wind barbs). 
peaks. Both the environmental flow-mountain interactions and thermally-driven circulations and their interactions with several peaks along the east-west oriented ridge of the Dabie Mountains may have played a role in triggering the line of convection. The purpose of this paper is to investigate the roles of the dynamic and thermal effects of the Dabie Mountains in producing the low-level convergence forcing for CI, and this is achieved by producing and analyzing realistic numerical simulations of the 24 June 2010 case with the aid of local data assimilation.

The rest of this paper is organized as follows: In section 2 , the numerical experiments are introduced, including the numerical model and its configurations, as well as the observational datasets used. The results are analyzed and discussed in detail in section 3 . Section 4 presents a summary and conclusions.

\section{Numerical model, data and experiment de- sign}

Version 5.3.3 of ARPS (Xue et al., 2000, 2001, 2003) is used to perform the simulations in this study. ARPS is a non-hydrostatic atmospheric model suitable for mesoscale and convective-scale simulation and prediction. The model domain has $259 \times 259$ horizontal grid points and a $3-\mathrm{km}$ grid spacing (Fig. 4). In the vertical direction, 53 stretched levels are defined on a generalized terrain-following coordinate, with the vertical grid spacing increasing from about $20 \mathrm{~m}$ near the surface to about $800 \mathrm{~m}$ near the model top at a height of about $20 \mathrm{~km}$. ARPS is used in its full physics mode with the same configurations as used in Wang and Xue (2012).

NCEP operational GFS $0.5^{\circ}$ global analysis data are used to provide the lateral boundary conditions at $6 \mathrm{~h}$ intervals, and a 6-h forecast is first produced using the 1800 UTC 23 June 2010 GFS analysis as the initial condition background. Using the 6-h forecast as the background, the ARPS threedimensional variational (3DVAR) system (Gao et al., 2004) is then used to assimilate conventional radiosonde and surface (not radar) data (see station sites in Fig. 4) at 0000 UTC 24 June. This final analysis is used as the initial condition by the control (CNTL) experiment, and by experiment NoHEAT (Table 1), which is the same as CNTL except that the radiation physics and surface sensible and latent heat fluxes in ARPS are turned off to isolate the thermal effects associated with the Dabie Mountains. In another sensitivity experiment, NoWIND, the model is initialized at 0000 UTC 24 June from a sounding instead of the three-dimensional fields from ARPS 3DVAR. This sounding is created by averaging the 0000 UTC 24 June GFS analysis in the Dabie Mountains region but with the wind set to zero; the sounding is shown in Fig. 3. As an idealized experiment, this simulation

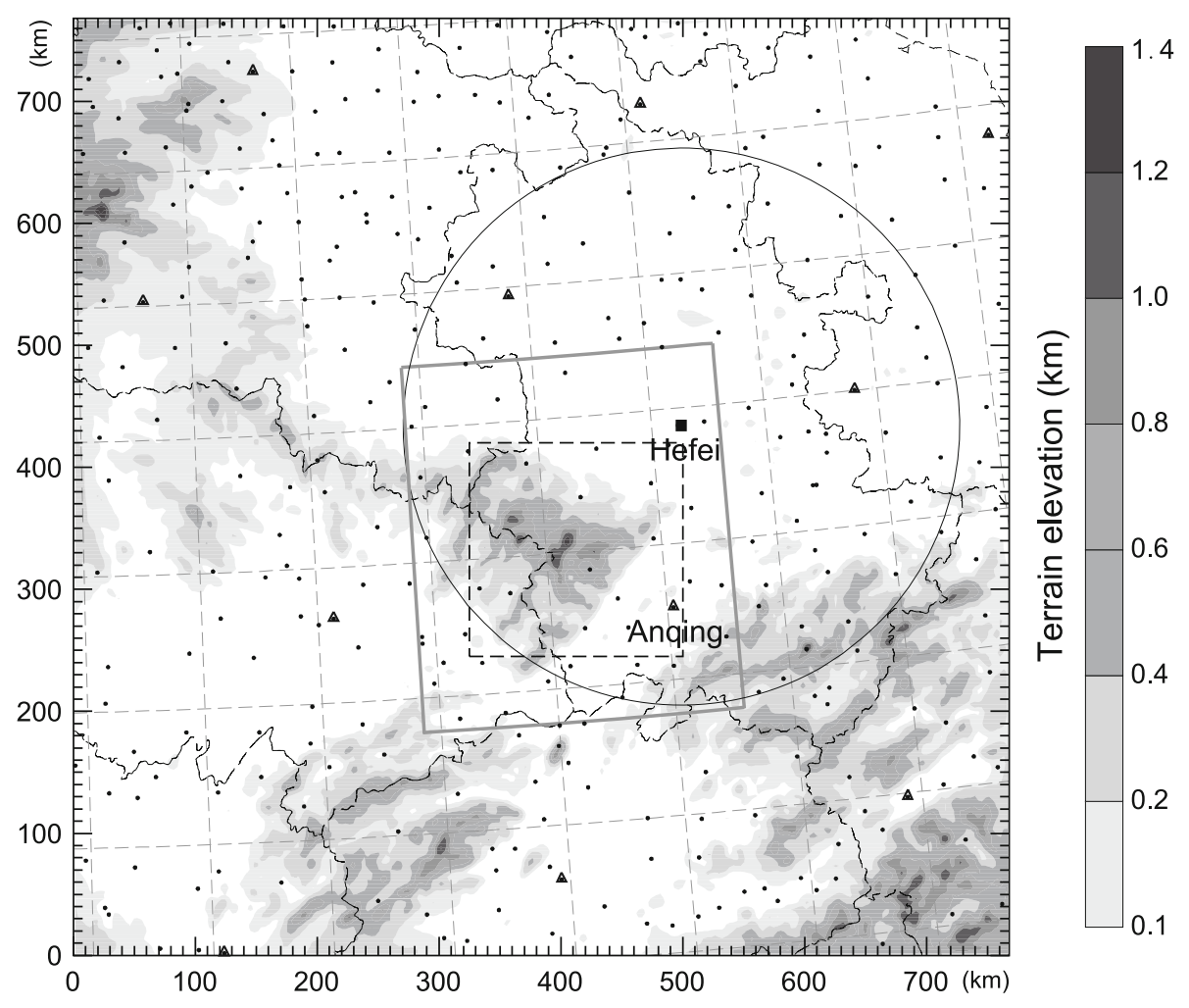

Fig. 4. The $3 \mathrm{~km}$ model domain with terrain elevation shaded. The filled square marks the Hefei radar location, with the large circle indicating the maximum radar range. The triangles and small filled circles indicate the stations from conventional radiosonde and surface networks, respectively. The Anqing sounding site is labelled. The dashed box denotes the plotting region in later figures. The solid gray box indicates the red box region in Fig. 1. 
Table 1. Control and sensitivity experiments.

\begin{tabular}{|c|c|c|c|}
\hline Experiment & Dynamic effects & Thermal effects & Description \\
\hline CNTL & Yes & Yes & $\begin{array}{l}\text { Initialized from ARPS 3DVAR analysis at } 0000 \text { UTC } 24 \text { June, using 6-h ARPS } \\
\text { forecast starting from } 1800 \text { UTC } 23 \text { June GFS analysis as the analysis back- } \\
\text { ground. }\end{array}$ \\
\hline NoWIND & No & Yes & $\begin{array}{l}\text { Initialized using a sounding constructed by averaging GFS analysis at } 0000 \\
\text { UTC } 24 \text { June over the Dabie Mountains region, but with wind set to zero. } \\
\text { Land surface model initial conditions are the same as in CNTL. }\end{array}$ \\
\hline NoHEAT & Yes & No & $\begin{array}{l}\text { Initial condition the same as in CNTL, but with radiation physics and surface } \\
\text { sensible and latent heat fluxes turned off. }\end{array}$ \\
\hline
\end{tabular}

uses the open (radiation) lateral boundary condition instead of GFS analyses as in CNTL and NoHEAT. This experiment is designed to remove the dynamic forcing associated with environmental flow-mountain interactions. In other words, it helps isolate the dynamic effects from thermodynamic effects.

\section{Results}

The simulated initiation and evolution of convection in a line pattern in CNTL are compared with radar observations in terms of the composite (column maximum) reflectivity in Fig. 5. Three convective cells first initiate at 0330 UTC in the simulation (Fig. 5a), with their locations close to the mountain peaks on the eastward-extending ridge line of the Dabie Mountains. The observed composite radar reflectivity at 0430 UTC first shows three areas of convection with locations close to the three convective cells in the simulation (Fig. 5b), and even closer to the location of the simulated cells in Fig. 5a one hour earlier. This indicates reasonably good agreement between the simulated and observed CIs, albeit the simulated CIs occur slightly too early (by nearly one hour). Despite the timing error of the initial CI, the simulated convective line is more comparable to the observation by 0530 UTC (Fig. 5c), due to the quick development of the convective cells and organization into a convective line. The exact reason for the CI timing error is difficult to ascertain. Both model and initial condition errors can cause such an er- ror, but we suspect excessive mountain thermal forcing as a cause. In general, predicting the initiation and evolution of individual convective cells is more difficult to achieve than for mesoscale convective systems, as pointed out by Kain et al. (2013). Because the main goal of this study is to investigate the physical processes responsible for the CI, rather than to obtain the most accurate forecast, we feel that the timing error, while not desirable, does not greatly affect our analysis of the physical processes. In fact, similar timing errors were seen in CIs in the study of Wang and Xue (2012), and they too compared model simulations and observations despite the time shift, as is the case here. Overall, the observed convective line is reasonably well simulated in CNTL. The timing and other differences in the detail do not prevent efforts to understand the processes associated with CI, as were attempted, with good successes, for example, in Xue and Martin (2006a, 2006b) and Wang and Xue (2012).

\subsection{The CIs forced by low-level convergence in CNTL}

The CIs and subsequent convection evolution from CNTL are shown in Fig. 6. A low-level convergence line actually forms before the convection line formation. At 0000 UTC 24 June 2010 (Fig. 6a), the dynamic effects of the Dabie Mountains in a weak near-surface easterly flow seem to play the main role. The near-surface flows generally go around the main mountain peaks, producing divergent flows on the windward side and convergence on the lee side. The thermal effects of the mountains due to radiation heating become
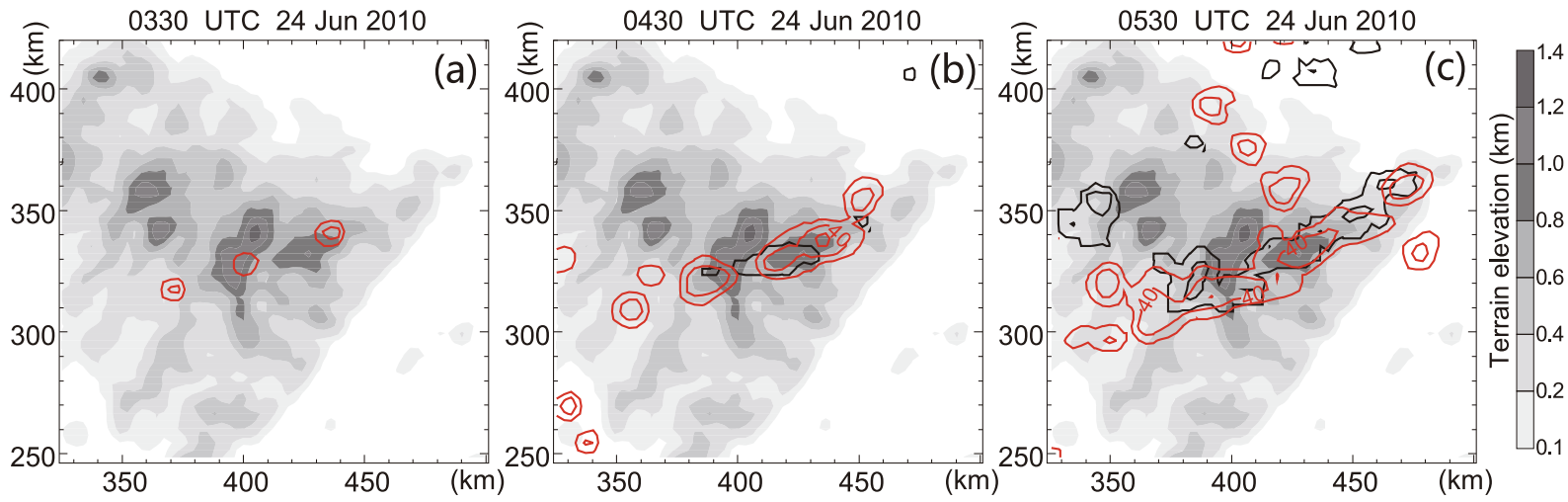

Fig. 5. Observed (black contours) and CNTL experiment simulated (red contours) composite radar reflectivity at 0330 UTC, 0430 UTC and 0530 UTC 24 June 2010. Both the black and the red contours are at intervals of $20 \mathrm{dBZ}$ and start from $20 \mathrm{dBZ}$ level. The terrain elevation is shaded. 

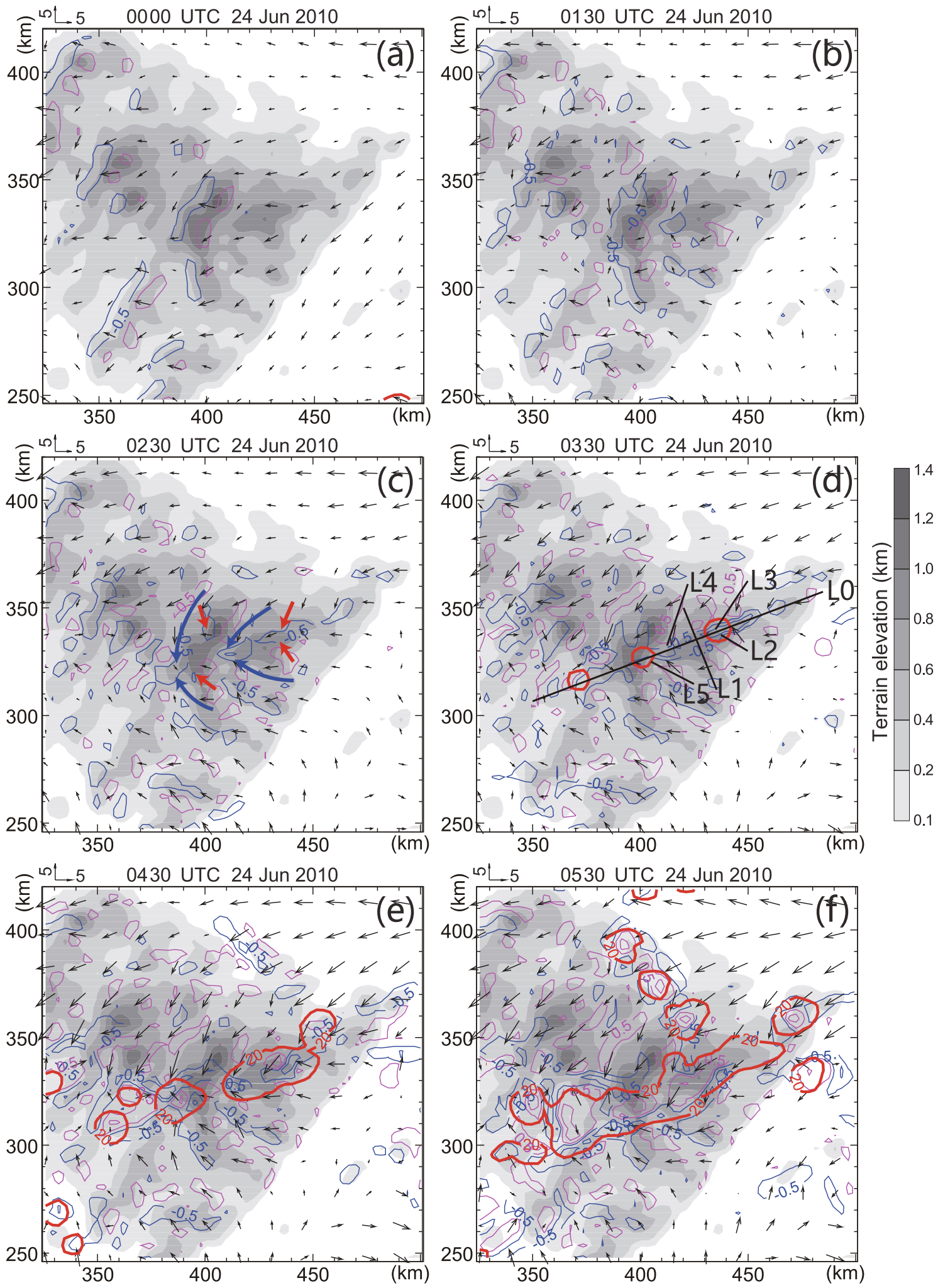

Fig. 6. Composite radar reflectivity of $20 \mathrm{dBZ}$ (bold red contours), near-surface (about $20 \mathrm{~m}$ above ground level) wind vectors and divergence [contours (negative, blue; positive, pink)] from CNTL at (a) 0000 UTC, (b) 0130 UTC, (c) 0230 UTC, (d) 0330 UTC, (e) 0430 UTC, and (f) 0530 UTC 24 June 2010. The contour levels for divergence are $-2 \times 10^{-3}$, $-0.5 \times 10^{-3}, 0.5 \times 10^{-3}$ and $2 \times 10^{-3} \mathrm{~s}^{-1}$. The bold blue and red arrows in (c) schematically outline the dynamically and thermally driven flows, respectively. In (d), line L0 indicates the position of the vertical cross sections shown in Fig. 8 and Fig. 10. Vertical cross sections through line L1 and L2-L5 in (d) are shown in in Fig. 11 and Fig. 12, respectively. The terrain elevation is shaded. 
active one and a half hours later at 0130 UTC (Fig. 6b) and patches of convergence and divergence are now found above the mountain peaks. At this time, both dynamic and thermal effects are present, while the thermal effects tend to become more dominant into the late morning hours (Figs. 6c and $\mathrm{d}$ ). Given the moderate easterly background flow, the dynamically-driven flows (schematically denoted as bold red arrows in Fig. 6c) clearly induce leeside convergence zones; the thermally-driven upslope winds are expected to converge from both (south and north) sides of the eastward extending ridge line of the mountains (schematically denoted as bold blue arrows in Fig. 6c), which is roughly along the line through mountain peaks P1 and P2, as denoted in Fig. 2a.

The thermally-forced convergence zones along the ridge combined with the dynamically-induced leeside convergence zones establish a somewhat organized line of convergence along the ridge by 0230 UTC (Fig. 6c), after which this line becomes more organized and the convergence zones are more or less connected by 0330 UTC (Fig. 6d). At this time, the thermally-forced convergence areas over the main mountain peaks can be recognized with locations slightly biased towards the downwind side of the peaks due to the weak nearsurface easterly environmental flows. Such convergence areas merge with and enhance the dynamically-driven leeside convergence areas (e.g., the convergence features over mountain peak P1 in Fig. 6d). By 0330 UTC (Fig. 6d), three convective cells, as indicated by the bold $20 \mathrm{dBZ}$ contours, have already been initiated over the convergence line, with one (the westernmost cell) to the leeside of mountain peak P1, the second between $\mathrm{P} 1$ and $\mathrm{P} 2$, and the third on the windward side of P2 (the easternmost cell). The three convective cells continue to develop along the convergence line over the next couple of hours and organize through mergers (Fig. 6e) until a full line of convection forms by 0530 UTC (Fig. 6f).

The dynamic and/or thermal convergence forcing along the convergence line that contributes to the initiation of the three initial convective cells can be more clearly identified at the $900 \mathrm{~m}$ MSL level in Fig. 7. At this level, the dynamic blocking effects of the main mountain peaks are less affected by the thermal effects that gradually develop from below due to mountain surface heating. At 0130 (Fig. 7a), convergence on the lee side of the main mountain peaks are induced by the around-peak flows, which are characterized by pairs of positive and negative vorticity centers attached to the mountain peaks (Fig. 7b), as discussed in Wang and Tan (2009). By 0230 UTC (Fig. 7c), the convergence features at the $900 \mathrm{~m}$ level have been affected by the thermally-driven convergence developing from the surface (Fig. 6b, c), with enhanced convergence found between mountain peaks P1 and P2 and new convergence patches on the north and east sides of mountain peak P2 (Figs. 7a and c). A slight enhancement of vertical vorticity at the $900 \mathrm{~m}$ level is also found by 0230 UTC (Figs. 7b and d), which indicates the modification of the around-peak flows by the thermal effects of the Dabie Mountains. By 0330 UTC (Fig. 7e), the convergence field tends to be dominated by the thermally-driven convergence, although the around-peak flows and the associated leeside convergence also act to enhance the overall convergence (Fig. 7f). The locations of the three convective cells relative to the convergence zones at this level (Fig. 7e) and near the surface (Fig. $6 \mathrm{~d})$ suggest that the dynamically- and thermally-driven convergence forcing both contribute to the CIs of the first and second (the westernmost and middle) cells, while the initiation of the third, easternmost, cell is mainly associated with thermal forcing effects.

The CI processes associated with the low-level convergence forcing are more clearly seen in Fig. 8 in vertical cross sections along the primary convergence line (L0 in Fig. 6d). The dynamic leeside convergence is clear at 0130 UTC when the thermal effects are weak, while the associated lifting forcing at this time is not strong and only induces shallow clouds (Fig. 8a). As the thermal effects become stronger, the leeside convergence is also enhanced, with the convergence between peaks P1 and P2 becoming connected with the area of relatively weak thermally-driven convergence on the windward side of P2 (Fig. 8b). The forcing over the enhanced leeside convergence has induced deeper clouds on the leeside of mountain peaks P1 and P2 at 0230 UTC (Fig. 8b), which subsequently develop into the first and second convective cells at 0330 UTC (Fig. 8c). The relatively weak, mostly thermally forced convergence upwind of P2 at 0230 UTC only induces shallower clouds (Fig. 8b), but it develops quickly and generally exceeds the dynamic leeside convergence, resulting in the more intense third (easternmost) convective cell (as indicated by the bold red contours of reflectivity) by 0330 UTC (Fig. 8c).

At 0330 UTC, intense forcing associated with the much stronger low-level convergence of greater than $2 \times 10^{-3} \mathrm{~s}^{-1}$ supports the initiation of the second (middle) and third (easternmost) convective cells (Figs. 6d, 7e and 8c). The strong convergence between mountain peaks $\mathrm{P} 1$ and $\mathrm{P} 2$ does not appear to be due to the thermally enhanced leeside convergence only, as the enhanced convergence on the lee side of peak P1 is similar but the overall convergence is not as strong. Also, the strong convergence on the windward side of mountain peak P2 cannot be explained by the thermal effects only, because the thermally-driven convergence should be near the mountain peaks and shifted slightly downwind by the easterly background flow, as with that over mountain peak P1. The Dabie Mountains feature southwest-northeast oriented (northwest-southeast oriented) mountain valleys (denoted as lines L2 through L5 in Fig. 6d) on the north (south) sides of the eastward extending main ridge line. In an easterly flow, these valleys can enhance up-valley winds toward the ridge line (e.g., the stronger wind vectors pointing along the valley in Figs. 6c-e), roughly where the areas of stronger convergence are located (Figs. 6d, 7e and 8c). This suggests that upvalley winds can make further contributions to produce even stronger convergence that forces the initiation of the second and the third convective cells.

For the first three initiations along the primary convergence line, it is not clear if dynamic leeside convergence forcing only is enough for the initiation of the first and second cells. It is also unclear how the leeside convergence is 

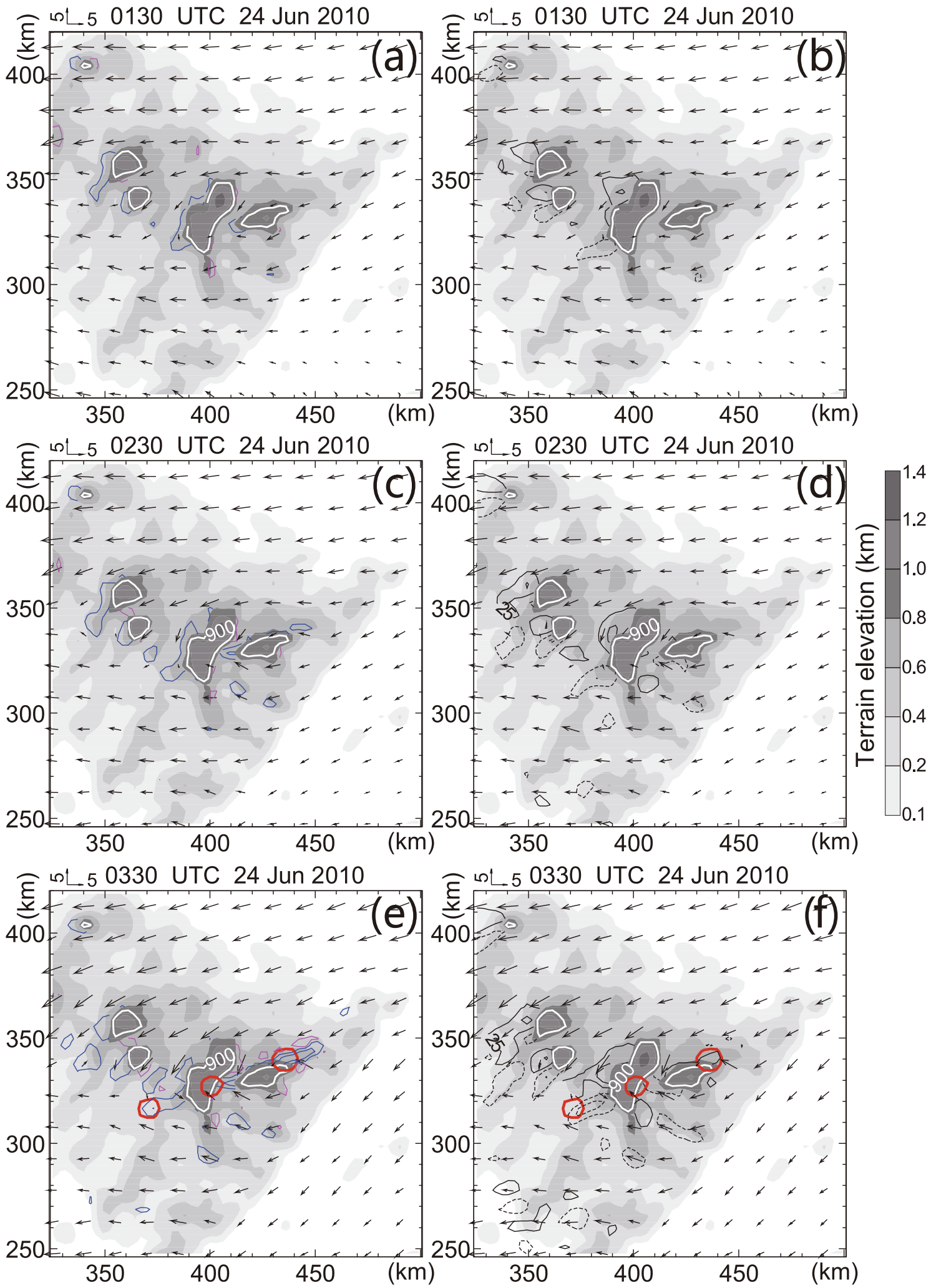

Fig. 7. Wind fields (vectors) and (a, c, e) divergence [contours (negative, blue; positive, pink], or (b, d, f) relative vertical vorticity [black contours (negative, dashed; positive, solid] at $900 \mathrm{~m}$ MSL from CNTL at (a, b) 0130 UTC, (c, d) 0230 UTC and (e, f) 0330 UTC 24 June 2010. The contour levels for divergence in (a, c, e) are $-2 \times 10^{-3},-0.5 \times 10^{-3}$, $0.5 \times 10^{-3}$ and $2 \times 10^{-3} \mathrm{~s}^{-1}$, and for vorticity in (b, d, f) are $-7.5 \times 10^{-4},-2.5 \times 10^{-4}, 2.5 \times 10^{-4}$ and $7.5 \times 10^{-4} \mathrm{~s}^{-1}$. The bold red contours are for the $20 \mathrm{dBZ}$ composite radar reflectivity. The terrain elevation is shaded. The $900 \mathrm{~m}$ terrain elevation is outlined in white contours. 


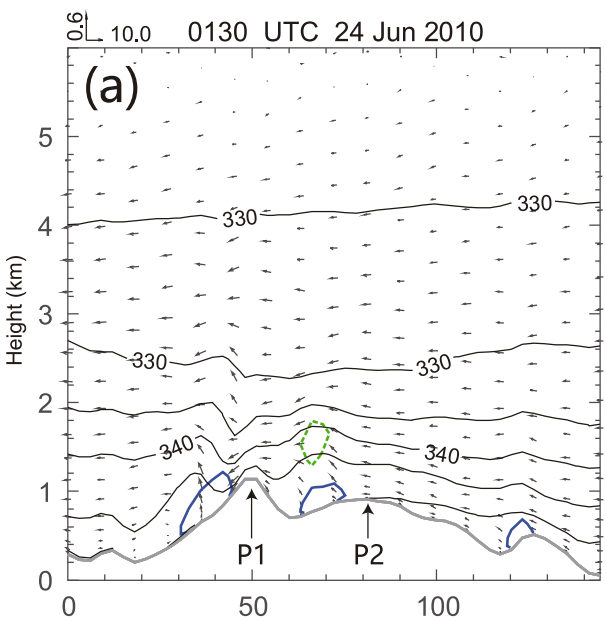

¿.t $10.0 \quad 0230$ UTC 24 Jun 2010

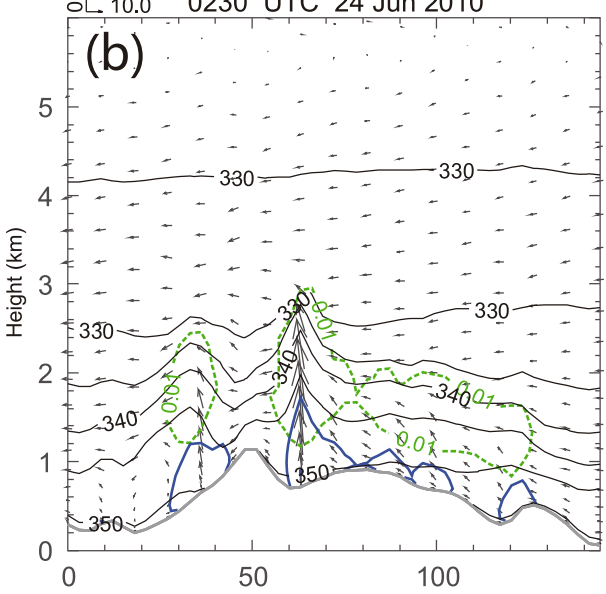

ơ $10.0 \quad 0330$ UTC 24 Jun 2010

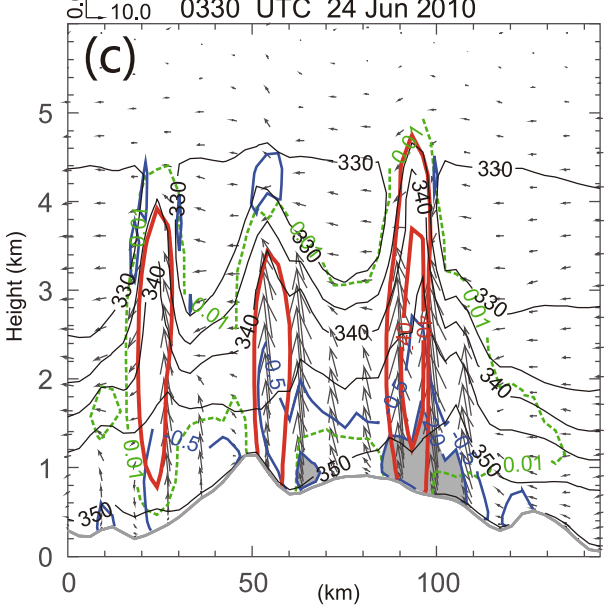

Fig. 8. Wind fields (wind vectors projected to the plane of the vertical cross section), convergence (blue contours, $\mathrm{s}^{-1}$ ), equivalent potential temperature (thin black contours, $\mathrm{K}$ ), total water mixing ratio (dashed green contours, $\mathrm{g} \mathrm{kg}^{-1}$ ), and radar reflectivity (bold red contours at $20 \mathrm{dBZ}$ intervals starting from 20 $\mathrm{dBZ}$ level) in the vertical cross section through line L0 in Fig. 6d, at (a) 0130 UTC, (b) 0230 UTC and (c) 0330 UTC 24 June 2010. The convergence is shown at the levels of 0.5 and $2 \times 10^{-3}$ $\mathrm{s}^{-1}$, with strong convergence greater than $2 \times 10^{-3} \mathrm{~s}^{-1}$ shaded in gray. The total water mixing ratio of $0.01 \mathrm{~g} \mathrm{~kg}^{-1}$ outlines the clouds. The mountain peaks P1 and P2 are denoted in (a). enhanced by the thermal effects, and how the thermal convergence forcing is dynamically modified. Moreover, the additional up-valley wind convergence is suggested to promote the initiation of the second and third cells, but how it works needs to be further examined. The roles of the dynamicallydriven, thermally-driven, and valley-enhanced convergence for the three initial CIs along the primary convergence line over the ridge are further examined via sensitivity experiments in the following subsections.

\subsection{Thermally-driven versus dynamically-driven conver- gence}

Figures 9 and 10 show the results of experiments NoWIND and NoHEAT, designed to examine the contributions of thermal and dynamic effects, respectively. They show that the thermally-driven convergence alone can induce forcing strong enough to trigger convection (left panels of Figs. 9 and 10), while the dynamically-driven convergence alone cannot (right panels of Figs. 9 and 10). By the time of CI at 0330 UTC, the near-surface maximum thermally-driven convergence right above the mountain peaks can reach a value greater than $2 \times 10^{-3} \mathrm{~s}^{-1}$ (Fig. 9a), while the dynamicallydriven convergence is only around $0.5 \times 10^{-3} \mathrm{~s}^{-1}$ and is generally attached to the lee sides of mountain peaks or ridges (Fig. 9b).

At the $900 \mathrm{~m}$ level, there are areas of convergence extending away from the $900 \mathrm{~m}$ contour of terrain elevation in NoWIND, which indicates that the thermally-driven convergence can reach this level (Fig. 9c). The position of the convergence extending along mountain peaks P1 and P2 in NoWIND is generally consistent with that in CNTL, but the convergence in NoWIND is rather weak (Figs. 9c and 7e). The dynamically-driven leeside convergence in NoHEAT (Fig. 9d) is also consistent with that in CNTL, which is more clearly shown earlier at 0130 UTC in Fig. 7a. Apparently, the dynamically-driven leeside convergence in NoHEAT is also weaker than that in CNTL, when comparing the associated around-peak flow and the vertical vorticity pairs (Figs. 9f and 7f).

In the vertical cross sections through the primary convergence line (line L0 in Fig. 6d), the thermally-driven convergence in NoWIND is right over individual mountain peaks, and the associated forcing is strong enough to trigger convection (left panels of Fig. 10). The dynamically-driven convergence in NoHEAT roughly maintains a quasi-steady pattern similar to that in Fig. 8a, which is weak and only induces shallow clouds (right panels of Fig. 10). The thermallyforced convective cells over mountain peaks P1 and P2 correspond to those on the lee side of P1 and P2 in CNTL (Fig. 8 ), which are linked to the forcing of both thermally-driven and dynamically-driven convergence. Note that the clouds mainly form on the lee side of the lower mountain peak P2 in NoHEAT (Fig. 10f). The convergence below the clouds is weaker than that on the lee side of the higher mountain peak P1 at 0130 UTC (Fig. 10b) but is stronger later (Fig. 10f). This suggests that the valley-enhanced convergence through channeling plays a role for the thicker clouds forming be- 

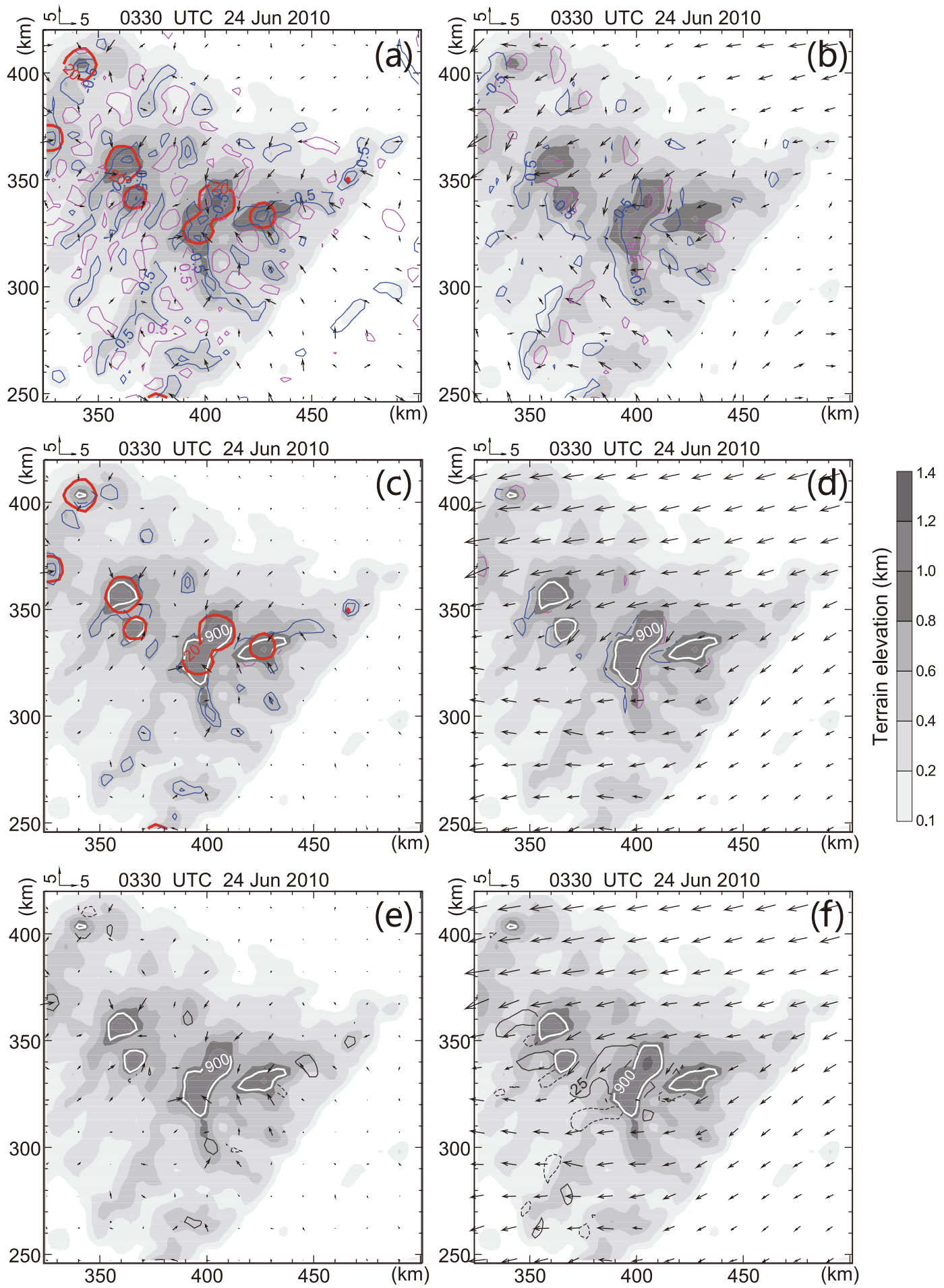

Fig. 9. Horizontal cross sections from (a, c, e) NoWIND and (b, d, f) NoHEAT at 0330 UTC 24 June 2010. Fields shown in (a, b), (c, d) and (e, f) are the same as in Figs. 6a-c and Figs. 7b-f, respectively. The terrain elevation is shaded. The bold red contours are for $20 \mathrm{dBZ}$ composite reflectivity.

tween P1 and P2. The clouds upwind of mountain peaks P1 and $\mathrm{P} 2$ are very shallow, suggesting that dynamic upslope lifting is weak given the weak near-surface easterly flow.

The different features between the sensitivity experiments and CNTL suggest that complex interactions between the thermal and dynamic effects exist in CNTL. The interactions are illustrated in the vertical cross sections through line L1 shown in Fig. 6d (Fig. 11), which is roughly perpendicular to the background flow and through mountain peak P2. The thermally-driven convergence is evidently modified by the dynamic effects in CNTL. The thermally-driven convergence is the strongest at mountain peak P2 in NoWIND, being en- 


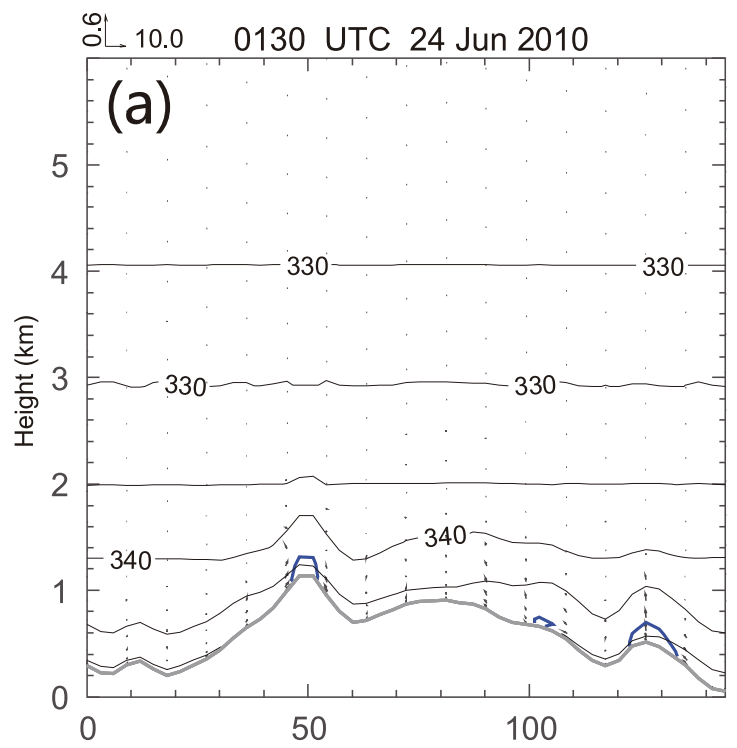

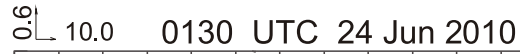
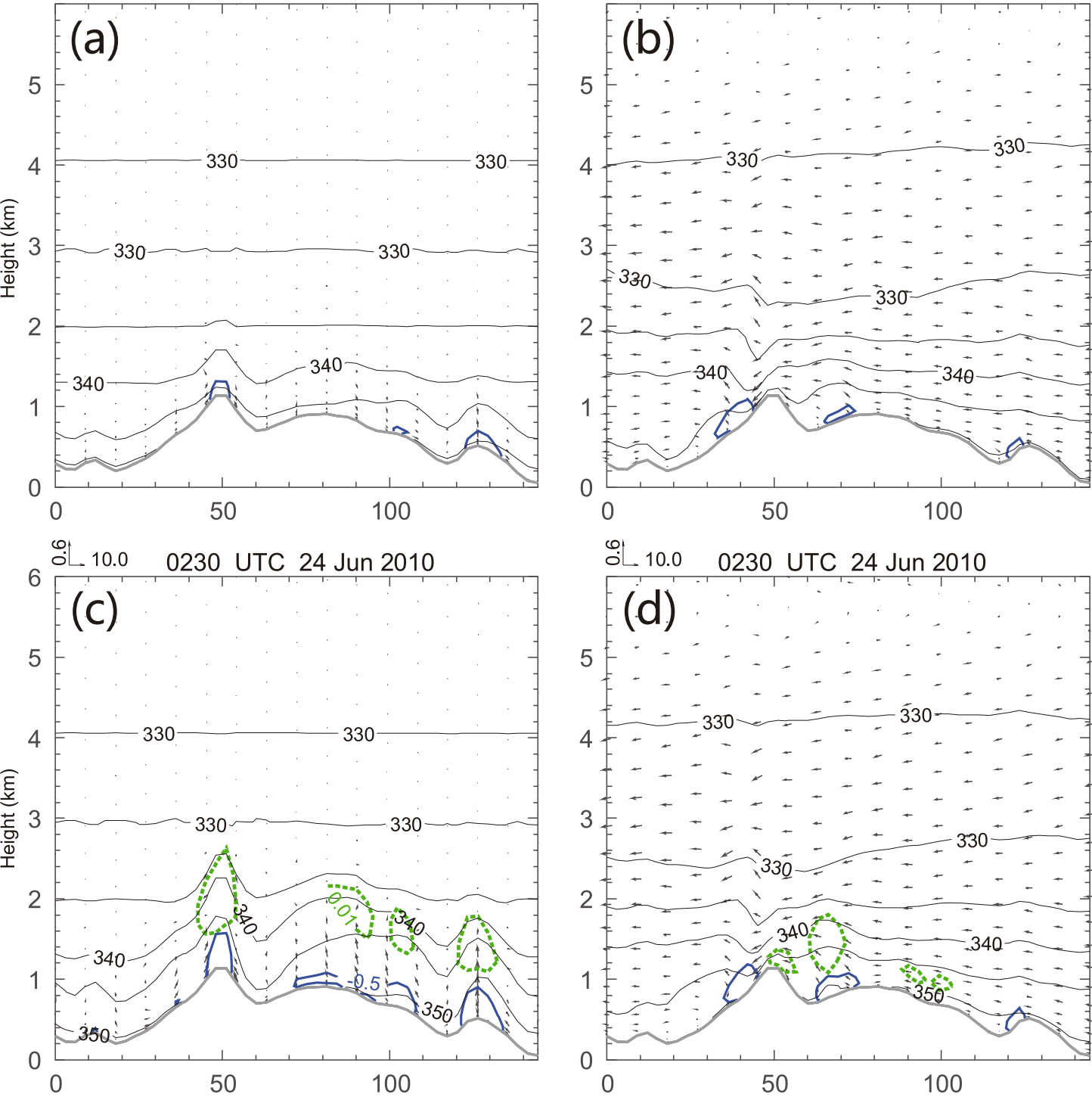

:. $10.0 \quad 0230$ UTC 24 Jun 2010
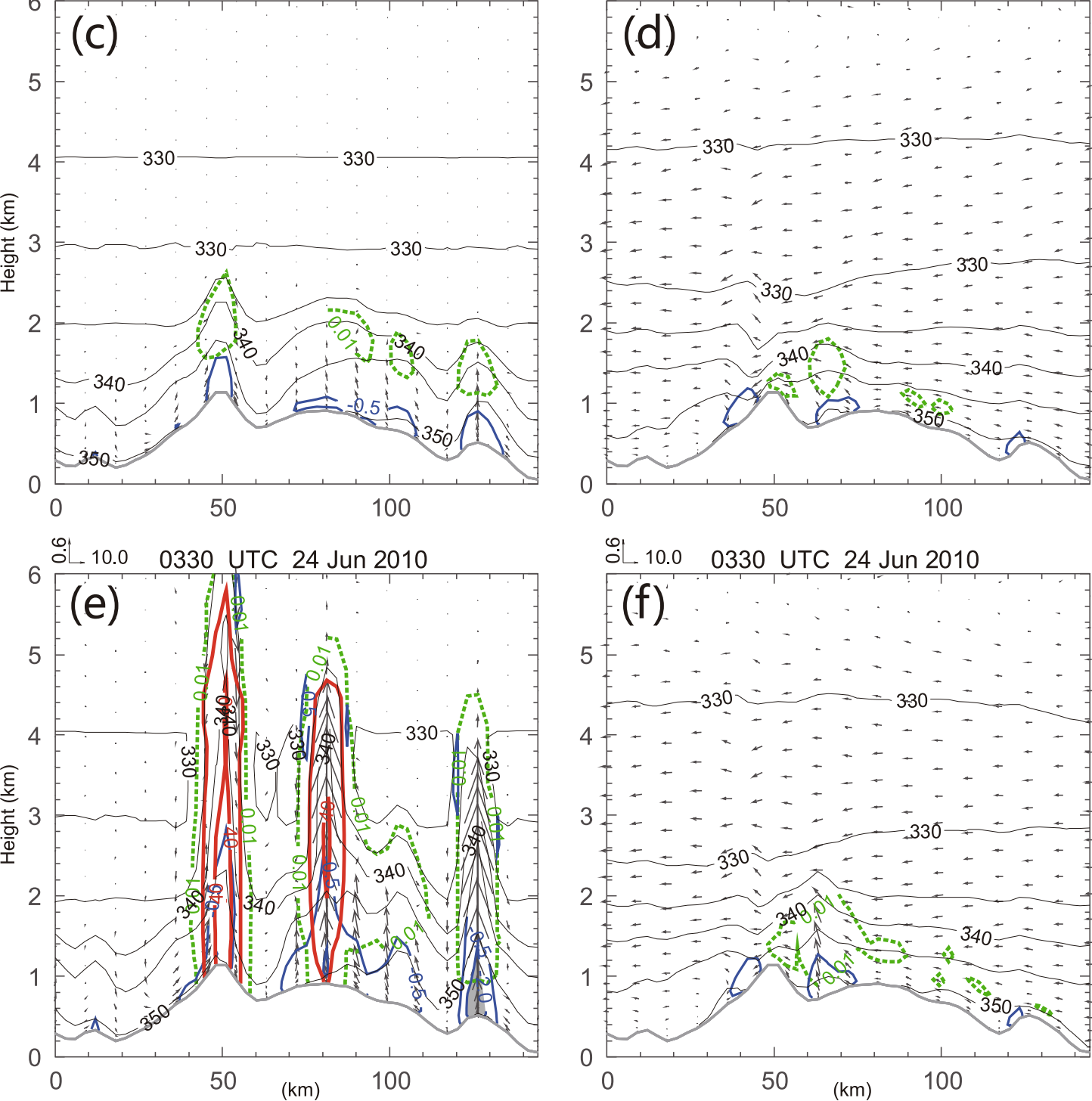

:. $10.0 \quad 0330$ UTC 24 Jun 2010

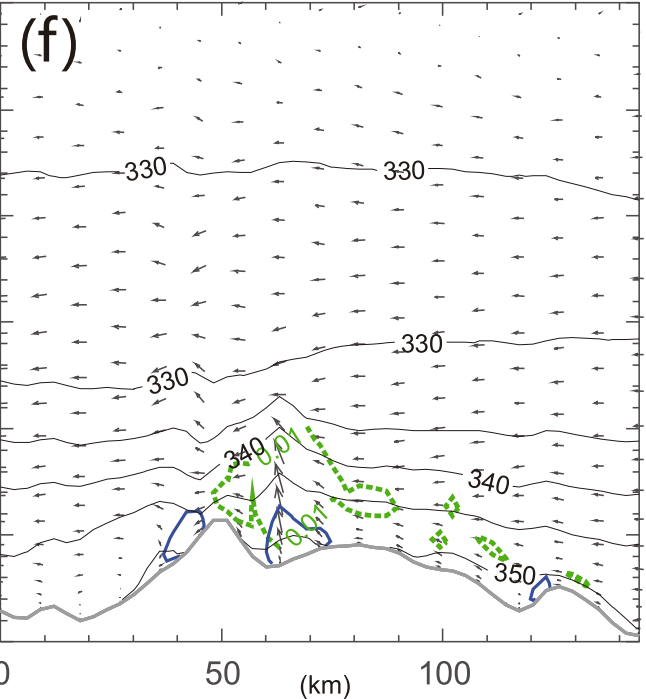

Fig. 10. As in Fig. 8, but for (a, c, e) NoWIND and (b, d, f) NoHEAT. 
hanced by the convergence between strong upslope winds on both the south and north sides of the ridge (Fig. 11a). But the thermally-driven convergence in CNTL is weaker, mainly due to the much weaker upslope winds on the south side of mountain peak P2 (on the right side of Figs. 11a and c). The weaker upslope winds on the south side in CNTL (Fig. 11c) are due to the expected strong upslope winds being advected downstream by the easterly background flow (Fig. 11f) and are therefore not found in this vertical cross section. The upslope winds on the north side of mountain peak P2 (left side of Fig. 11c) are also affected by the flow advection but the difference is less in the direction of background winds because the terrain on the north side of mountain peak P2 is almost uniform in the direction of the easterly flow. The upslope winds on the north side of mountain peak P2 (left side of Fig. 11a) in NoWIND are comparable to that in CNTL (left side of Fig. 11c), suggesting that the sounding used to initialize NoWIND captures the main thermodynamic characteristics of the background flow over the Dabie Mountains in CNTL. The advection of the thermally-driven upslope convergence winds by the background flow results in a downwind shift of the convergence in CNTL (Fig. 8c) relative to that in NoWIND above mountain peaks $\mathrm{P} 1$ and $\mathrm{P} 2$ (Fig. 10e).

On the other hand, the dynamically-driven convergence is also modified by the thermal effects in CNTL. One important role of the thermal effects is to enhance the around- peak flows. The thermal effects also induce easterly winds (Fig. 11d) because the overall terrain slopes upward toward the center of the Dabie Mountains. The thermally-induced easterly winds enhance the dynamically-driven around-peak flows (Fig. 11e) and result in stronger around-peak flows in CNTL (Fig. 11f). The enhanced around-peak flows are associated with the vertical vorticity attached to the mountain peaks in CNTL (Fig. 7f), which is stronger than that in NoHEAT (Fig. 9f).

It is expected that we can obtain low-level convergence structures similar to those in CNTL (Fig. 8c) by adding the thermally-driven (Fig. 10e) and dynamically-driven convergence (Fig. 10f) and taking into account the thermal and dynamic interactions discussed above. Upon doing so, it is found that the much stronger convergence on the windward side of P2 and between P1 and P2 (shaded in Fig. 8c) still cannot be fully explained. As discussed in section 3.1 , the strong convergence is believed to be associated with the additional convergence enhancement by valleys, which is discussed next.

\subsection{Valley-enhanced convergence}

Figure 12 shows the winds along the valleys, in vertical cross sections along lines L2, L3, L4, and L5 in Fig. 6d. The thermal effects alone in NoWIND can induce up-valley winds greater than $2.5 \mathrm{~m} \mathrm{~s}^{-1}$ (Figs. 12a, d, g and j), which rise along
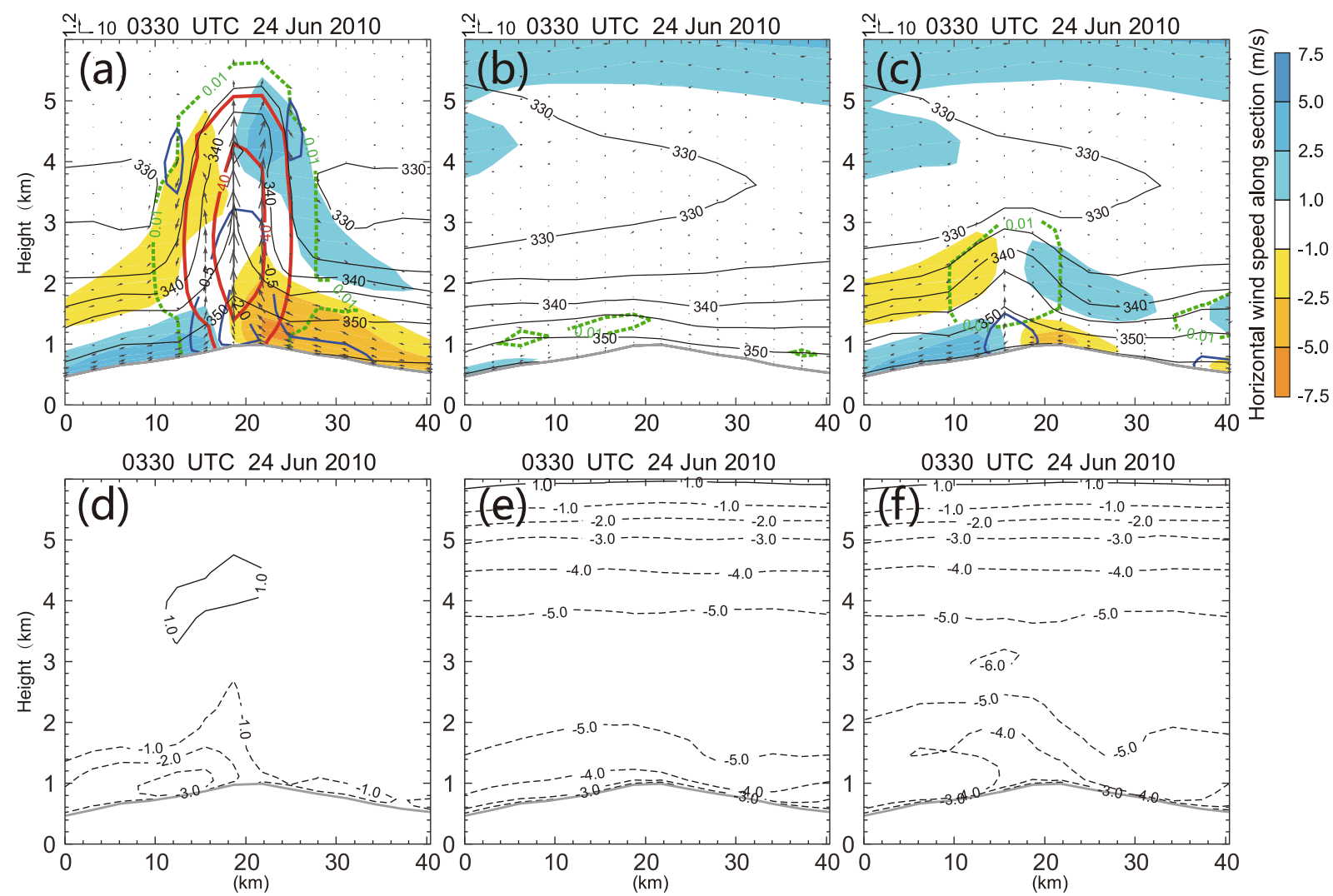

Fig. 11. Vertical cross sections from (a, d) NoWIND, (b, e) NoHEAT and (c, f) CNTL through line L1 in Fig. 6d at 0330 UTC 24 June 2010. Fields shown in $(\mathrm{a}-\mathrm{c})$ are the same as in Fig. 8, except horizontal wind speed (color-shaded) along the cross section is additionally shown. Horizontal wind speed perpendicular to the cross section is shown in (d-f). 

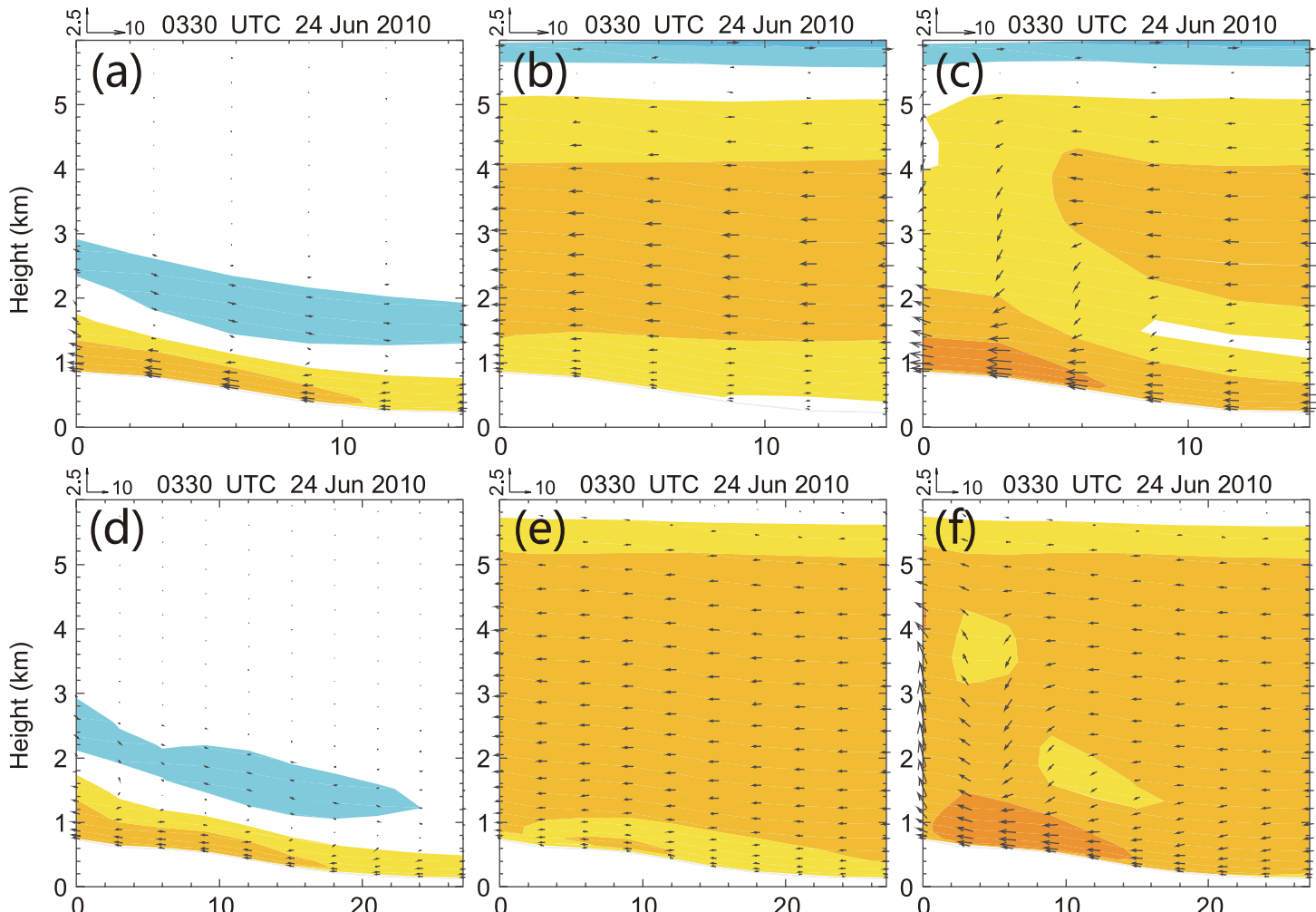

ڤ̊L.10 0330 UTC 24 Jun 2010
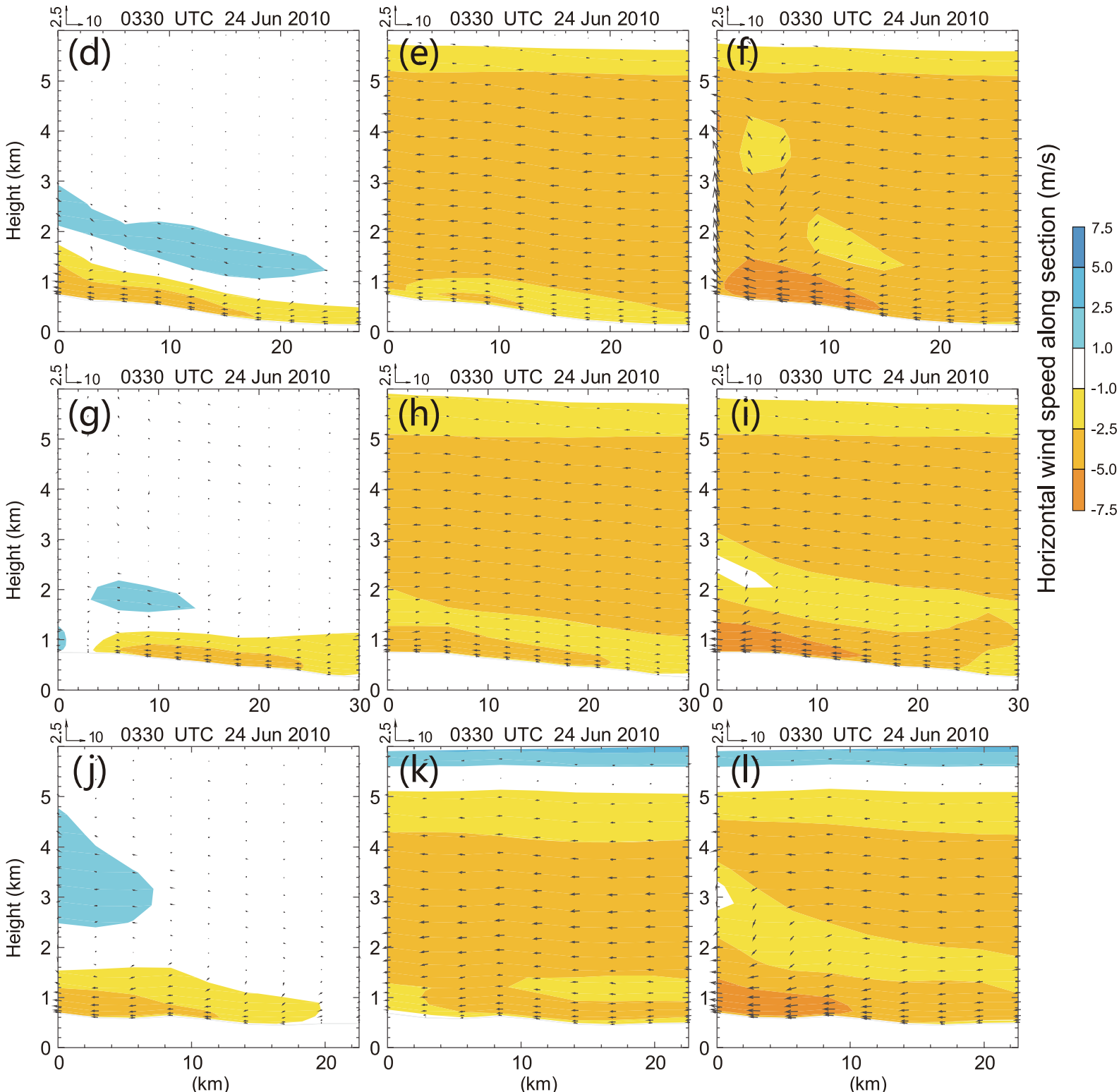

Nit-10 0330 UTC 24 Jun 2010

Fig. 12. Wind vectors and horizontal wind speed (color-shaded) along vertical cross sections from (a, d, g, j) NoWIND, (b, e, h, k) NoHEAT and (c, f, i, l) CNTL through lines (a-c) L2, (d-f) L3, (g-i) L4 and (j-1) L5 in Fig. 6d at 0330 UTC 24 June 2010.

the slopes and meet at the ridge line to force upward motion. The up-valley winds induced purely by dynamic channeling effects in NoHEAT are also clear along the valleys (Figs. $12 \mathrm{~b}, \mathrm{e}, \mathrm{h}$ and $\mathrm{k}$ ). In CNTL, the up-valley winds include both thermally-driven and dynamically-channeled winds along the valleys and are therefore stronger, with values greater than 5 $\mathrm{m} \mathrm{s}^{-1}$ (Figs. 12c, $\mathrm{f}$, i and l). In addition, the wind speed (momentum) at approximately $4 \mathrm{~km}$ is slightly larger than that 
between this level and the near-surface layer (Figs. 12c, f, $i$ and 1), and vertical circulation induced by thermal forcing will help transfer momentum from above, resulting in acceleration of momentum near the surface layer. This process is similar to the winds associated with low-level open convective cells discussed in Xue and Martin (2006b). The stronger up-valley winds in CNTL reach the upper valley ends (Figs. $12 \mathrm{c}, \mathrm{f}, \mathrm{i}$ and $\mathrm{l}$ ), and converge to produce the strongest upward motion at the ridge top among the three experiments, confirming the additional contributions made by the valley thermal and dynamic channeling effects on the windward slope of $\mathrm{P} 2$ and between $\mathrm{P} 1$ and $\mathrm{P} 2$.

\section{Summary and conclusions}

Convective initiation by topographically induced lowlevel convergence forcing over the Dabie Mountains during
24 June 2010 is studied through numerical simulations with sensitivity experiments using the ARPS model, run at a $3 \mathrm{~km}$ horizontal grid spacing. The synoptic background over the Dabie Mountains is characterized by a moderate low-level easterly flow on the north side of a Mei-yu front. The initiation of the three earliest convective cells along a primary lowlevel convergence line aligned along the eastward-extending Dabie Mountains ridge is reasonably well simulated.

The formation of the primary low-level convergence line along the ridge and the locally enhanced convergence regions along the line that produce the initial CIs involve dynamic, thermal, and topographic effects associated with the Dabie Mountains and their interactions with the weak environmental flow. The key processes involved are summarized in a conceptual model illustrated in Fig. 13. In a moderate low-level easterly flow that roughly parallels the eastwardextending ridge line of the Dabie Mountains, the convergence
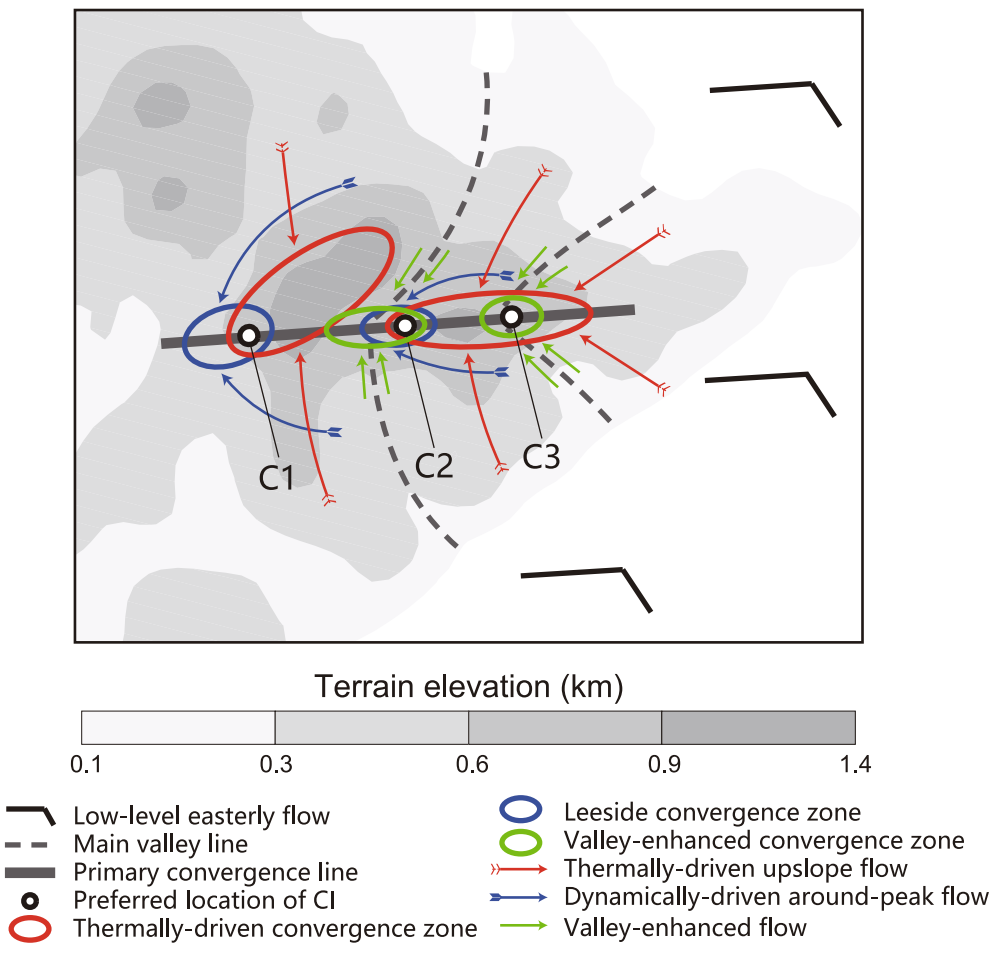

Fig. 13. Conceptual model for the formation of low-level convergence regions and the primary convergence line over the eastward-extending Dabie Mountains ridge in a moderate low-level easterly flow (indicated by the wind barbs). The thermally-driven upslope winds in the late morning (shown by red curved arrows with feather tails) induce convergence zones (red ellipses) over the main mountain peaks along the ridge. Additional convergence zones are induced on the leeside of the main mountain peaks on the ridge (blue ellipses) by aroundpeak flows (shown as blue curved arrows with rhomboid tails). Further, upslope winds (green short arrows) along the roughly north-south oriented valleys (thick dashed lines), due to thermal and channeling effects, create additional convergence zones (green ellipses) between the peaks along the ridge. The superposition of the flow convergence due to the above processes creates a primary convergence line (bold solid line) along the eastward-extending ridge line of the Dabie Mountains, with locally enhanced convergence centers (three small white-filled black circles labeled $\mathrm{C} 1$ through $\mathrm{C} 3$ ) that tend to initialize convection the quickest. The terrain elevation is shaded. See text for further detail. 
zones induced by the thermally-driven upslope winds during late morning are more or less aligned along the ridge line. Instead of being right over mountain peaks, the thermallydriven convergence zones shift slightly downwind from the mountain peaks on the ridge in the moderate easterly environmental flow. The dynamically-driven around-peak flows create convergence zones on the lee side of individual mountain peaks. In addition, valley-enhanced upslope winds due to thermal and dynamic channeling converge at the ridge top from the north and south sides of the ridge and produce another form of convergence zones along the ridge. In the easterly background flow, the three forms of convergence zones are organized along the eastward-extending ridge line of the Dabie Mountains to form a primary low-level convergence line. Locally enhanced convergence centers are found along the primary convergence line due to superposition of two or three forms of the convergence zones. The locally enhanced convergence centers on the primary convergence line provide the strongest forcing that initiates the earliest convective cells, which eventually organize into a line of convection.

Sensitivity experiments with the surface heating and the environmental flow removed, respectively, show that the thermal effects play a dominant role in the CIs along the primary convergence line. In addition to directly inducing thermallydriven convergence, the thermal effects also strengthen the dynamically-driven leeside convergence by enhancing the around-peak flows through the upslope effect. The thermallydriven vertical circulations can additionally transfer larger momentum from above to the near surface layer to further enhance the up-valley winds, which are both thermallyinduced and dynamically-forced through the channeling effect. Knowledge of the dynamic, thermal, and topographic effects of the Dabie Mountains and their interactions with the environmental winds are helpful for the understanding and prediction of precipitation events in the Dabie Mountains region.

Acknowledgements. This work was primarily supported by the National Natural Science Foundation of China (Grant Nos. 41375061, 41130964 and 41461164008), the National Program on Key Basic Research project (973) (Grant Nos. 2013CB430103 and 2012CB417200), and the Special Public Sector Research of China (Grant No. GYHY201006004). The GFS data used to initialize the simulations were downloaded from the NCAR Data Archive. We are grateful to the HPCC (High Performance Computing Center) of Nanjing University for carrying out the numerical calculations reported in this paper, on its IBM Blade cluster system. We thank the three anonymous reviewers, whose comments improved the manuscript.

Open Access. This article is distributed under the terms of the Creative Commons Attribution 4.0 International License (http://creativecommons.org/licenses/by/4.0/), which permits unrestricted use, distribution, and reproduction in any medium, provided you give appropriate credit to the original author(s) and the source, provide a link to the Creative Commons license, and indicate if changes were made.

\section{REFERENCES}

Bao, X. H., F. Q. Zhang, and J. H. Sun, 2011: Diurnal variations of warm-season precipitation east of the Tibetan Plateau over China. Mon. Wea. Rev., 139, 2790-2810.

Bennett, L. J., and Coauthors, 2011: Initiation of convection over the Black Forest mountains during COPS IOP15a. Quart. J. Roy. Meteor. Soc., 137, 176-189.

Bosart, L. F., 2003: Whither the weather analysis and forecasting process? Wea. Forecasting, 18, 520-529.

Chen, S.-J., Y.-H. Kuo, W. Wang, Z.-Y. Tao, and B. Cui, 1998: A modeling case study of heavy rainstorms along the Mei-yu front. Mon. Wea. Rev., 126, 2330-2351.

Chow, F. K., S. F. J. De Wekker, and B. J. Snyder, 2013: Mountain Weather Research and Forecasting: Recent Progress and Current Challenges. Springer, $750 \mathrm{pp}$.

Crook, N. A., and D. F. Tucker, 2005: Flow over heated terrain. Part I: Linear theory and idealized numerical simulations. Mon. Wea. Rev., 133, 2552-2564.

Demko, J. C., and B. Geerts, 2010: A numerical study of the evolving convective boundary layer and orographic circulation around the Santa Catalina mountains in Arizona. Part II: Interaction with deep convection. Mon. Wea. Rev., 138, 36033622.

Ding, Y. H., 1992: Summer monsoon rainfalls in China. J. Meteor Soc. Japan, 70, 337-396.

Ding, Y.-H., J.-J. Liu, Y. Sun, Y.-J. Liu, J.-H. He, and Y.-F. Song, 2007: A study of the synoptic-climatology of the Meiyu system in East Asia. Chinese J. Atmos. Sci., 31, 1082-1101. (in Chinese)

Fu, S. M., F. Yu, D. H. Wang, and R. D. Xia, 2012: A comparison of two kinds of eastward-moving mesoscale vortices during the mei-yu period of 2010. Science China Earth Sciences, 56, 282-300.

Gao, J. D., M. Xue, K. Brewster, and K. K. Droegemeier, 2004: A three-dimensional variational data analysis method with recursive filter for Doppler radars. J. Atmos. Oceanic Technol., 21, 457-469.

Guo, R., C. S. Miao, and N. Zhang, 2013: Sensitivity experiments of effects of Dabie mountains terrain on Meiyu front rainstorm over Huaihe River basin. Transactions of Atmospheric Sciences, 36, 626-634. (in Chinese)

Hagen, M., J. van Baelen, and E. Richard, 2011: Influence of the wind profile on the initiation of convection in mountainous terrain. Quart. J. Roy. Meteor. Soc., 137, 224-235.

Horel, J., and Coauthors, 2002: Mesowest: Cooperative mesonets in the western United States. Bull. Amer. Meteor. Soc., 83, 211-226.

Houze, R. A., Jr., 2012: Orographic effects on precipitating clouds. Rev. Geophys., 50, RG1001.

Kain, J. S., and Coauthors, 2013: A feasibility study for probabilistic convection initiation forecasts based on explicit numerical guidance. Bull. Amer. Meteor. Soc., 94, 1213-1225.

Luo, Y. L., H. Wang, R. H. Zhang, W. M. Qian, and Z. Z. Luo, 2013: Comparison of rainfall characteristics and convective properties of monsoon precipitation systems over south China and the Yangtze and Huai River basin. J. Climate, 26, 110 132

Miao, C. S., W. X. Liu, J. H. Wang, M. Wu, and T. Li, 2014: Comparison between two rainstorm meso-scale vortices circumambulated respectively from two sides of Mountain Dabieshan during Meiyu season. Plateau Meteorology, 
33, 394-406. (in Chinese)

Rotunno, R., and R. A. Houze, 2007: Lessons on orographic precipitation from the Mesoscale Alpine Programme. Quart. J. Roy. Meteor. Soc., 133, 811-830.

Schmidli, J., and R. Rotunno, 2010: Mechanisms of along-valley winds and heat exchange over mountainous terrain. J. Atmos. Sci., 67, 3033-3047.

Soderholm, B., B. Ronalds, and D. J. Kirshbaum, 2014: The evolution of convective storms initiated by an isolated mountain ridge. Mon. Wea. Rev., 142, 1430-1451.

Sun, J. H., and F. Q. Zhang, 2012: Impacts of mountain-plains solenoid on diurnal variations of rainfalls along the Mei-yu front over the East China Plains. Mon. Wea. Rev., 140, 379397.

Sun, J. H., X. L. Zhang, L. L. Qi, and S. X. Zhao, 2005: An analysis of a meso- $\beta$ system in a mei-yu front using the intensive observation data during CHeRES 2002. Adv. Atmos. Sci., 22, 278-289, doi: 10.1007/BF02918517.

Tao, S. Y., 1980: Heavy Rain in China. Science Press, 225 pp.

Trier, S. B., G. S. Romine, D. A. Ahijevych, R. J. Trapp, R. S. Schumacher, M. C. Coniglio, and D. J. Stensrud, 2015: Mesoscale thermodynamic influences on convection initiation near a surface dryline in a convection-permitting ensemble. Mon. Wea. Rev., 143, 3726-3753.

Tucker, D. F., and N. A. Crook, 2005: Flow over heated terrain. Part II: Generation of convective precipitation. Mon. Wea. Rev., 133, 2565-2582.

Wang, Q. W., and Z. M. Tan, 2006: Flow regimes for major topographic obstacles of China. Chinese Journal of Geophysics, 49, 971-982.

Wang, Q. W., and Z.-M. Tan, 2009: Idealized numerical simulation study of the potential vorticity banners over a mesoscale mountain: Dry adiabatic process. Adv. Atmos. Sci., 26, 906922, doi: 10.1007/s00376-009-8004-z.

Wang, Q. W., and M. Xue, 2012: Convective initiation on 19 June 2002 during IHOP: High-resolution simulations and analysis of the mesoscale structures and convection initiation. J. Geophys. Res., 117, D12107.

Worthington, R. M., 2015: Organisation of orographic convection by mountain waves above Cross Fell and Wales. Weather, 70, $186-188$.

Wulfmeyer, V., and Coauthors, 2008: RESEARCH CAMPAIGN:
The convective and orographically induced precipitation study. Bull. Amer. Meteor. Soc., 89, 1477-1486.

Xue, M., and Coauthors, 2001: The Advanced Regional Prediction System (ARPS) - A multi-scale nonhydrostatic atmospheric simulation and prediction tool. Part II: Model physics and applications. Meteor. Atmos. Phys., 76, 143-165.

Xue, M., and W. J. Martin, 2006a: A high-resolution modeling study of the 24 May 2002 dryline case during IHOP. Part I: Numerical simulation and general evolution of the dryline and convection. Mon. Wea. Rev., 134, 149-171.

Xue, M., and W. J. Martin, 2006b: A high-resolution modeling study of the 24 May 2002 dryline case during IHOP. Part II: Horizontal convective rolls and convective initiation. Mon. Wea. Rev., 134, 172-191.

Xue, M., K. K. Droegemeier, and V. Wong, 2000: The Advanced Regional Prediction System (ARPS) - A multi-scale nonhydrostatic atmospheric simulation and prediction model. Part I: Model dynamics and verification. Meteor. Atmos. Phys., 75, 161-193.

Xue, M., D. H. Wang, J. D. Gao, K. Brewster, and K. K. Droegemeier, 2003: The Advanced Regional Prediction System (ARPS), storm-scale numerical weather prediction and data assimilation. Meteor. Atmos. Phys., 82, 139-170.

Yang, Y. M., W. L. Gu, R. L. Zhao, and J. Liu, 2010: The statistical analysis of low vortex during Meiyu season in the lower reaches of the Yangtze. Journal of Applied Meteorological Science 21, 11-18. (in Chinese)

Zhang, J., and Z. M. Tan, 2009: A simulation study of the mesoscale convective systems associated with a Meiyu frontal heavy rain event. Acta Meteor. Sinica, 23, 438-454. (in Chinese)

Zhao, Y. C., 2015: A study on the heavy-rain-producing mesoscale convective system associated with diurnal variation of radiation and topography in the eastern slope of the western Sichuan plateau. Meteor. Atmos. Phys., 127 123-146.

Zhao, Y. C., X. F. Xu, and C. G. Cui, 2012: Case study of the impact of mesoscale topography on the Meiyu frontal rainstorm. Plateau Meteorology, 31, 1268-1282. (in Chinese)

Zhong, S. Y., and J. Fast, 2003: An evaluation of the MM5, RAMS, and Meso-Eta models at subkilometer resolution using VTMX field campaign data in the Salt Lake valley. Mon. Wea. Rev., 131, 1301-1322. 